INDEPENDENT JOURNAL OF MANAGEMENT \& PRODUCTION (IJM\&P)

http://www.ijmp.jor.br

v. 12, n. 8, November-December 2021

ISSN: 2236-269X

DOI: 10.14807/ijmp.v12i8.1487

\title{
BALLAST WATER MANAGEMENT: TECHNOLOGY CHOICE COMPARING TODIM AND THOR 2
}

Carlos Francisco Simões Gomes

Department of Production Engineering, Fluminense Federal University, Brazil

E-mail: cfsg1@bol.com.br

Luiz Flavio Autran Monteiro Gomes Ibmec School of Business and Economics, Ibmec University Center, Brazil E-mail: luiz.gomes@professores.ibmec.edu.br

Luís Alberto Duncan Rangel Department of Production Engineering, Fluminense Federal University, Brazil E-mail: luisduncan@id.uff.br

Fabricio Maione Tenório Federal Center of Technological Education Celso Suckow da Fonseca, Brazil. E-mail: fabricio.tenorio@cefet-rj.br

Marcos dos Santos Military Engineering Institute, Brazil E-mail: marcosdossantos@ime.eb.br

Submission: $11 / 6 / 2020$ Revision: $12 / 16 / 2020$ Accept: 12/1/2020

\section{ABSTRACT}

This paper approaches the problem of ballast water treatment in ships. This has been identified as one of the four greatest threats to the world's oceans. Solutions that have been considered for solving the problem are alternative water treatment technologies. In the case study reported in this paper three major water treatment technologies have been evaluated with the help of twenty-six criteria, quantitative as well as qualitative by using two discrete multicriteria methods, TODIM and THOR 2. The THOR 2 consists of the axiomatic evolution of the THOR method and both THOR 2 and THOR are made available through the THOR Web platform. Five groups of evaluation criteria are then considered: practicality; biological effectiveness; cost/benefit ratio; time frame for the implementation of standards; and environmental impact of the process' subproducts. In this paper a case study on choosing a ballast water treatment technology is presented. 
INDEPENDENT JOURNAL OF MANAGEMENT \& PRODUCTION (IJM\&P)

http://www.ijmp.jor.br

v. 12, n. 8, November-December 2021

ISSN: 2236-269X

DOI: 10.14807/ijmp.v12i8.1487

Three alternative ballast water management technologies are proposed by experts in the field and are evaluated with the help of twenty-six criteria, quantitative as well as qualitative. Each ballast water management method is described by a list of twenty-six attributes or criteria. After setting the problem in a clear way and consulting different experts, the two separate applications of both TODIM and THOR 2 are performed. What is denoted as Management Method \#1 is indeed chosen as the best alternative according to both methods. The conclusion is that those two methods, although conceptually and analytically quite different, lead essentially to the same main results. Two other applications of both TODIM and THOR have indeed confirmed the convergence of results in spite of the conceptual and technical differences between the two methods. This suggests that formulating a decision problem in a correct, clearcut way can be at least as important as the technical characteristics of the method per se.

Keywords: Maritime transportation; Water pollution, TODIM, THOR 2, Multi-Criteria Decision Analysis

\section{INTRODUCTION}

A number of research efforts on ballast water have been carried out due to its global importance (IMO, 2020a). The introduction of invasive marine species into new environments by ships' ballast water attached to ships' hulls and via other vectors has been identified as one of the four greatest threats to the world's oceans. Shipping moves over $80 \%$ of the world's commodities and transfers approximately 3 to 5 billion tons of ballast water internationally each year. A similar volume may also be transferred domestically within countries and regions each year. Ballast water is essential to the safe and efficient operation of modern merchant ships, providing balance and stability to unloaded ships. However, it may also pose a serious ecological, economic and health threat.

Here it is worth observing that ballast is any material used to weight and/or balance an object. One example are the sandbags carried on conventional hot-air balloons, which can be discarded to lighten the balloon's load, allowing it to ascend. Ballast water is therefore water carried by ships to ensure stability, trim and structural integrity. Ships have carried solid ballast, in the form of rocks, sand or metal, for thousands of years. In modern times, ships use water as ballast.

It is estimated that at least 7,000 different species are being carried in ships' ballast tanks around the world. Research on various types of marine life has been conducted by different authors (Tenenbaum et al., 2004). The vast majority of marine species carried in ballast water 
DOI: 10.14807/ijmp.v12i8.1487

do not survive the journey, as the ballasting and deballasting cycle and the environment inside ballast tanks can be quite hostile to organism survival. Even for those that do survive a voyage and are discharged, the chances of surviving in the new environmental conditions, including predation by and/or competition from native species are further reduced. However, when all factors are favorable, an introduced species can survive to establish a reproductive population in the host environment, becoming invasive, out-competing native species and multiplying into pest proportions (IMO, 2020b).

The so-called ballast water cycle comprises the following stages: (1) the ship is unloaded and therefore with no ballast, the sea water then functioning as ballast water; (2) the ship moves with ballast water taken from the starting port; (3) the ship discharges ballast water and places exogenous marine life in the destination port; (4) the ship is loadless and does not require ballast water anymore.

As the situation becomes more and more serious, the International Maritime Organization (IMO) has sponsored international meetings to find out courses of action to meet this challenge, where the subject is discussed by the IMO Member States.

As a result, whole ecosystems are being changed. In the USA, the European zebra mussel dreissena polymorph has infested over $40 \%$ of internal waterways and may have required between US\$750 million and US\$ 1 billion in expenditure on control measures between 1989 and 2000. In southern Australia, the Asian kelp undaria pinnatifida is invading new areas rapidly, displacing the native seabed communities. In the Black Sea, the filterfeeding North American jellyfish mnemiopsis leidyi has on occasion reached densities of $1 \mathrm{~kg}$ of biomass per m2. It has depleted native plankton stocks to such an extent that it has contributed to the collapse of entire Black Sea commercial fisheries.

In several countries, introduced, microscopic, 'red-tide' algae (toxic dinoflagellates) have been absorbed by filter-feeding shellfish, such as oysters. When eaten by humans, these contaminated shellfish can cause paralysis and even death. The list goes on, with hundreds of examples of major ecological, economic and human health impacts across the globe. It is even feared that diseases such as cholera might be able to be transported in ballast water.

Invasive marine species are one of the four greatest threats to the world's oceans. The other three are land-based sources of marine pollution, overexploitation of living marine resources and physical alteration/destruction of marine habitat. Unlike other forms of marine pollution, such as oil spills, where ameliorative action can be taken and from which the 
environment will eventually recover, the impacts of invasive marine species are most often irreversible (IMO, 2020a).

In this paper a case study on choosing a ballast water treatment technology is presented. Three alternative ballast water management technologies are proposed by experts in the field and are evaluated with the help of twenty-six criteria, quantitative as well as qualitative. The problem is tackled by a multicriteria approach and two methods are utilized. Results from applying those two methods are the compared.

\section{CASE STUDY}

In 2002 a group of Brazilian scientists and engineers comprising fifteen civilian and four military experts and including members of the Brazilian delegation to IMO's International Conference on Ballast Water Management for Ships was asked to demonstrate the feasibility of evaluating alternative ballast water treatment technologies and to produce a ranking of those by using Multicriteria Analysis. The technical leadership was with one of the authors of this paper; their first challenge was to design the evaluation process. The multicriteria methods to be used should allow incorporating their value judgments based on their experiences as well as the experiences of IMO Member States. The evaluation process should be taken as a learning process. Finally, it should also provide a recommendation for selecting the best ballast water exchange and treatment methods.

The steps below were followed:

- Step 1: identify in all proposals submitted by IMO Member States the relevant criteria;

- Step 2: submit this set of criteria to IMO Member States;

- Step 3: obtain the consensus about the criteria set;

- Step 4: identify the alternatives that solve the problem;

- Step 5: submit the alternatives to IMO Member States;

- Step 6: identify the importance to criteria by their relative weights;

- Step 7: order the alternatives by both TODIM and THOR 2 .

Two multicriteria methods, TODIM and THOR 2, were used in the case study as separate analytical tools in this case study. After applying both methods, their results are compared. In order to apply this methodology to the case under consideration, relevant groups of criteria have been identified. They are: Practicality; Biological effectiveness (including 
DOI: 10.14807/ijmp.v12i8.1487

pathogens); Cost/benefits; Time frame within which the standards could be practically implemented; and Environmental impact of the process' sub-products.

\section{METHODOLOGY}

\subsection{The TODIM Method}

At the end of the 1970s, in the midst of the need for answers that covered several dimensions for decision-making processes, a new field of Management Sciences emerged, Multi-Criteria Decision Analysis (MCDA). Decision problems are often complex in nature, as they imply the consideration of multiple assessment criteria, uncertainties, conflicts of values and interests, asymmetries of power, and a large volume of data and information that, in turn, are often incomplete. This has been precisely the domain of action of MCDA (Ehrgott et al., 2010).

The various analytical methods of MCDA apply to all those complex decision problems that fit into at least one of the following four problematiques: choice, ranking, sorting, or description (ROY, 1996). Among these various multicriteria methods, there is one that, based on a robust psychological foundation, both in its original formulation and in extensions, has allowed solving problems inserted in those problematiques, the TODIM method.

The TODIM method was the very first methodological contribution of Brazilian researchers to the field of MCDA. The embryo of TODIM was a multicriteria ranking technique introduced at the end of the 80's (Gomes, 1989a; Gomes, 1989b; Gomes, 1990a; Gomes, 1990b). In 1991 the creator of such technique decided to provide a psychological basis for ranking alternatives under multiple criteria and this innovation led to the TODIM method as it is known today. Thus TODIM (an acronym in Portuguese for Interactive and Multicriteria Decision Making) (Gomes \& Lima, 1991; Gomes \& Lima, 1992; Sudha et al., 2020; Zindani et al., 2020) is a discrete multicriteria method founded on Prospect Theory (Kahneman \& Tversky, 1979).

While all other discrete multicriteria methods assume that the decision maker always looks for the solution corresponding to the maximum of some global measure of value - for example, the highest possible value of a multiattribute utility function, in the case of MAUT (Keeney\& Raiffa, 1993) - TODIM makes use of a global measurement of value calculable by the application of Prospect Theory. In this way, TODIM is based on a description, demonstrated by empirical evidence, of how people effectively make decisions in the face of risk. 
DOI: 10.14807/ijmp.v12i8.1487

Although not all multicriteria problems deal with risk, the shape of the value function of TODIM is the same as the value function of Prospect Theory. The multiattribute value function of TODIM is built in parts, with their mathematical descriptions reproducing that gain/loss function. The global multiattribute value function of TODIM therefore aggregates all measures of gains and losses over all criteria (Gomes \& Rangel, 2009; Gomes, Rangel \&Maranhão, 2009; Gomes et al., 2013).

The concept of introducing expressions of losses and gains in the same multiattribute function, present in the formulation of TODIM, gives this method some similarity to the PROMÉTHÉE methods, which make use of the notion of net outranking flow (Brans \& Mareschal, 1990). TODIM indeed maintains a similarity with outranking methods, because the global value of each alternative is relative to its dominance over other alternatives in the set. In its calculations the TODIM method is suitable to test specific forms of the losses and gains functions. Each one of the forms depends on the value of one single parameter. The forms, once validated empirically, lead to the additive difference function of the method. This notion of an additive utility function is borrowed from Tversky (Tversky, 1969).

From the construction of that additive difference function, which performs as a multiattribute value function and, as such, must also have its use validated by verifying the condition of mutual preferential independence (Clemen \& Reilly, 2001), the method leads to a global ordering of the alternatives. It can be observed that the construction of the multiattribute value function, or additive difference function, of the TODIM method is based on a projection of the differences between the values of any two alternatives (perceived in relation to each criterion) to a reference criterion.

The TODIM method makes use of paired comparisons between the decision criteria, using technically simple resources to eliminate occasional inconsistencies arising from these comparisons. It also allows value judgments to be carried out in a verbal scale, using a criteria hierarchy, fuzzy value judgments and making use of interdependence relationships among the alternatives. It is a non-compensatory method in the sense that tradeoffs are not dealt with in the modeling process (Bouyssou, 1986).

Consider a set of $n$ alternatives to be ordered in the presence of $m$ quantitative or qualitative criteria and assume that one of those criteria can be considered as the reference criterion. After the definition of these elements, experts are asked to estimate, for each one of 
INDEPENDENT JOURNAL OF MANAGEMENT \& PRODUCTION (IJM\&P)

http://www.ijmp.jor.br

v. 12, n. 8, November-December 2021

ISSN: 2236-269X

DOI: 10.14807/ijmp.v12i8.1487

the qualitative criteria $c$, the contribution of each alternative $i$ to the objective associated with the criterion.

This method requires the values of the evaluation, of the alternatives in relation to the criteria, to be numerical and to be normalized; consequently, the qualitative criteria evaluated in a verbal scale are transformed into a cardinal scale. The evaluations of the quantitative criteria are obtained from the performance of the alternatives in relation to the criteria, such as, for example, the level of noise measured in decibels, the power of an engine measured in horsepower or a student's mark in a subject etc.

Being an MCDA tool, TODIM was conceived be used with qualitative as well as quantitative evaluation criteria simultaneously considered. Verbal scales of qualitative criteria are converted to cardinal ones and both types of scales are normalized. The relative measure of dominance of one alternative over another is found for each pair of alternatives. This measure is computed as the sum over all criteria of both relative gain/loss values for these alternatives. The parts in this sum will be either gains, losses, or zeros, depending on the performance of each alternative with respect to every criterion.

The evaluation of the alternatives in relation to all the criteria produces the matrix of evaluation, where the values are all numerical. Their normalization is then performed, using, for each criterion, the division of the value of one alternative by the sum of all the alternatives. This normalization is carried out for each criterion, thus obtaining a matrix, where all the values are between zero and one. It is called the matrix of normalized alternatives' scores against criteria.

The application of TODIM then proceeds towards the computation of the overall value for each alternative. This is accomplished by making use of expressions for the gain/loss branches of the prospect theoretical value function. An important parameter of TODIM is $\theta$, the attenuation factor of the losses; different choices of $\theta$ lead to different shapes of the prospect theoretical value function in the negative quadrant.

The global measures obtained of alternatives' values computed by TODIM permit the complete rank ordering of all alternatives. A sensitivity analysis should then be applied to verify the stability of the results based on the decision makers' preferences. The sensitivity analysis should therefore be carried out on $\theta$ as well as on the criteria weights, the choice of the reference criterion, and performance evaluations. 
Mathematical expressions (1), (2) and (3) constitute the essential modeling underlying the use of TODIM:

$$
\begin{aligned}
& \delta\left(A_{i}, A_{j}\right)=\sum_{c=1}^{m} \Phi_{c}\left(A_{i}, A_{j}\right) \\
& \Phi_{c}\left(A_{i}, A_{j}\right)= \begin{cases}\frac{w_{r c}\left(P_{i c}-P_{j c}\right)}{\sum_{c=1}^{m} w_{r c}} & \text { if }\left(P_{i c}-P_{j c}\right)>0 \\
-\frac{0}{\theta} \sqrt{\frac{\left(\sum_{c=1}^{m} w_{r c}\right)\left(P_{j c}-P_{i c}\right)}{w_{r c}}} & \text { if }\left(P_{i c}-P_{j c}\right)=0\end{cases} \\
& \text { if }\left(P_{i c}-P_{j c}\right)<0 \\
& \xi_{i}=\frac{\sum_{j=1}^{n} \delta\left(A_{i}, A_{j}\right)-\min \sum_{j=1}^{n} \delta\left(A_{i}, A_{j}\right)}{\max \sum_{j=1}^{n} \delta\left(A_{i}, A_{j}\right)-\min \sum_{j=1}^{n} \delta\left(A_{i}, A_{j}\right)}
\end{aligned}
$$

where:

$\delta\left(A_{i}, A_{j}\right)$, measurement of dominance of alternative $A_{i}$ over alternative $A_{j}$;

$\mathrm{m}$, the number of criteria;

c, a generic criterion;

Wrc, trade-off rate between any criterion taken as a reference criterion $r$ and any other, generic criterion $c$;

$\mathrm{P}_{\mathrm{ic}}$ and $\mathrm{P}_{\mathrm{jc}}$, evaluations of alternatives $i$ and $j$ with respect to criterion $c$;

$\theta$, attenuation factor of the losses; different choices of $\theta$ lead to different shapes of the prospect theoretical value function in the negative quadrant.

$\Phi_{c}\left(A_{i}, A_{j}\right)$, contribution of criterion $c$ to function $\delta\left(A_{i}, A_{j}\right)$, when comparing alternatives $A_{i}$ and $\mathrm{A}_{j}$.

$\xi_{\mathrm{i}}$, normalized global performance of alternative $\mathrm{A}_{\mathrm{i}}$, when compared against all other alternatives.

The function Фс reproduces the Prospect Theory value function and replicates the most relevant shape characteristics. First, it fulfills the concavity for positive outcomes (convexity for negative outcomes) and second, it enlarges the perception of negative values for losses than positive values for gains, both value functions are steeper for negative outcomes than for positive ones. It is worth observing that, together with the value function, these two authors introduced the weighting function that measures the subjective perception of probabilities. As 
DOI: 10.14807/ijmp.v12i8.1487

TODIM is a deterministic method in its original formulation, only the value function is extended.

Each shape characteristic of the value function models psychological processes: The concavity for gains describes a risk aversion attitude, the convexity describes a risk seeking attitude; secondly, the assumption that losses carry more weight than gains is represented by a steeper negative function side.

Different kinds of decision makers can be understood in terms of their risk and loss attitude. Although the TODIM method does not deal with risk directly, the way the decision maker evaluates the outcomes of any decision can be expressed by their risk attitude: for instance, a cautious decision maker will under-valuate a superior result more than a braver one. Apart from parameter $\theta$, the attenuation factor of the losses, function $\Phi$ does not offer other parameters to delineate the behavior of diverse decision makers, therefore a generic formulation is proposed.

It is worth noticing that as soon as TODIM appeared in the MCDA literature the fact that this method has elements from both the so-called French and North American School was pointed out by Roy and Bouyssou (1993).

\subsection{The THOR 2 Method}

The THOR 2 consists of the axiomatic evolution of the THOR method (Tenório, 2020). THOR was the second MCDA tool created by a Brazilian researcher and was conceived as the essential product of a doctoral thesis (Gomes, 1999). THOR is an analytical approach that relies on concepts of Rough Set Theory, Fuzzy Set Theory and Preference Theory (Gomes et al., 2008). The mathematical model embedded in THOR comes by a combination those three theories and allows for the quantification of the attractiveness of each alternative by creating a non-transitive aggregation function (Costa et al., 2020).

THOR is therefore a tool for ranking discrete alternatives under multiple criteria, by eliminating redundant criteria and by reducing imprecision along the decision process. The concept of quantifying the imprecision associated to the weights and to the classification of the alternatives put into operation in THOR arises from the fact that the judgment values, because of their inherent subjectivity, cannot always be expressed in crisp ways. When using THOR, the simultaneous input of data into the process from multiple decision makers is also allowed, enabling those to express their judgment values in scales of ratios, intervals or ordinals, in 
INDEPENDENT JOURNAL OF MANAGEMENT \& PRODUCTION (IJM\&P)

http://www.ijmp.jor.br

v. 12, n. 8, November-December 2021

ISSN: 2236-269X

DOI: 10.14807/ijmp.v12i8.1487

addition to the execution of the decision making process without necessarily assigning weights to criteria (Gomes, 2005).

The analytical modeling embedded in THOR is based on the ELECTRE methods of the French School of MCDA. The following additional elements are then necessary for the application of THOR: a weight for each criterion, representing the relative importance among them; a preference threshold $(p)$ and another for indifference $(q)$ for each criterion; discordance; and pertinence of the values of the weights attributed to the criterion, as well as the pertinence of the classification of the alternative in the criterion.

Since its creation in 1999, THOR has been used for solving a diversity of problems within a multicriteria framework. Table 1 lists references to journal articles making use of THOR.

Table 1: Articles were THOR is used and types of applications

\begin{tabular}{|c|c|c|}
\hline Authors & Methods & Types of application \\
\hline Gomes (2005) & $\begin{array}{l}\text { THOR, ELECTRE, } \\
\text { PROMETHÉE II, } \\
\text { ELECTRE III, } \\
\text { AHP }\end{array}$ & $\begin{array}{c}\text { Analysis of a ballast water treatment } \\
\text { system }\end{array}$ \\
\hline Gomes (2006) & THOR & $\begin{array}{l}\text { Construction of an energy plant and } \\
\text { selection of a site for procurement }\end{array}$ \\
\hline Gomes et al. (2008) & THOR & $\begin{array}{l}\text { Disposition of plastic and construction } \\
\text { waste }\end{array}$ \\
\hline Cardoso et al. (2009) & THOR & $\begin{array}{c}\text { Destination of plastic and packaging } \\
\text { waste }\end{array}$ \\
\hline Gomes et al. (2010) & TODIM e THOR & Destination of natural gas \\
\hline Gomes and Maia (2013) & THOR & $\begin{array}{l}\text { Choice of biomass for producing } \\
\text { renewable energy }\end{array}$ \\
\hline Gomes and Costa (2015) & $\begin{array}{l}\text { THOR, ELECTRE } \\
\text { I, ELECTRE II, } \\
\text { PROMETHÉE II }\end{array}$ & Choice of credit card technology \\
\hline Tenório et al. (2020a) & THOR & $\begin{array}{l}\text { Strategy for buying a ship for the } \\
\text { Brazilian Navy }\end{array}$ \\
\hline Tenório et al. (2020b) & THOR & $\begin{array}{l}\text { Selection of a ship for the Brazilian } \\
\text { Navy }\end{array}$ \\
\hline Costa et al. (2020) & THOR 2 & $\begin{array}{c}\text { Choice of a ship for medical assistance } \\
\text { for COVID-19 }\end{array}$ \\
\hline
\end{tabular}

Given two alternatives $a$ and $b$, three situations can be considered when THOR is used: $\mathrm{S}_{1}, \mathrm{~S}_{2}$ and $\mathrm{S}_{3}$. Situation $\mathrm{S}_{1}$ only considers the alternatives $a$ for which $a P b$, with $b$ being any other alternative. In this way, comparing $a$ with $b$, we can identify the criteria in which $a P b$, taking into consideration the thresholds of preference ( $P$ designates strict preference and $Q$ designates weak preference), indifference and discordance, checking if the condition imposed is satisfied. If satisfied, we know that $a$ dominates $b$. The binary relations $P, Q$, and $I$ are defined as below. Equations (4), (5) and (6) designate the binary relations $P, Q$ and $I$, respectively, where the notation $g($.$) designates a criterion:$ 
DOI: 10.14807/ijmp.v12i8.1487

$$
\begin{aligned}
& a P b \leftrightarrow g(a)-g(b)>p \\
& a Q b \leftrightarrow q<|g(a)-g(b)| \leq p \\
& a I b \leftrightarrow-q \leq|g(a)-g(b)| \leq q
\end{aligned}
$$

We can therefore write Equation (7) for Situation 1 (or $\mathrm{S}_{1}$ ):

$$
S 1: \sum_{j=1}^{n}\left(w_{j} \mid a P_{j} b\right)>\sum_{j=1}^{n}\left(w_{j} \mid a Q_{j} b+a I_{j} b+a R_{j} b+b Q_{j} a+b P_{j} a\right)
$$

The context $S_{1}$ is characterized by the following fact: the sum of the weights of the criteria $j$ such what $a$ is strongly preferable $b$ is bigger than the sum of the weights of the criteria $j$ such what $a$ is weakly preferable $b$ more the sum of the weights of the criteria $j$ such what $a$ is indifferent $b$ more the sum of the weights of the criteria $j$ such what $a$ is not comparable with $b$ any more the sum of the weights of the criteria $j$ such what $b$ is weakly preferable $a$ to any more the sum of the weights of the criteria $j$ such what $b$ is strongly preferable to a.

Situation 2 (or $\mathrm{S}_{2}$ ) leads to Equation (8):

$$
S 2: \sum_{j=1}^{n}\left(w_{j} \mid a P_{j} b+a Q_{j} b\right)>\sum_{j=1}^{n}\left(w_{j} \mid a I_{j} b+a R_{j} b+b Q_{j} a+b P_{j} a\right)
$$

The context $S_{2}$ is characterized by the next fact: the sum of the weights of the criteria $j$ such what $a$ is strongly preferable $b$ and is weakly preferable $b$ is bigger than the sum of the weights of the criteria $j$ such what $a$ is weakly preferable $b$ more the sum of the weights of the criteria $j$ such what $a$ is indifferent $b$ more the sum of the weights of the criteria $j$ such what a is not comparable with $b$ any more the sum of the weights of the criteria $j$ such what $b$ is weakly preferable $a$ to any more the sum of the weights of the criteria $j$ such what $b$ is strongly preferable to $a$.

Situation 3 (or $S_{3}$ ) produces Equation (9):

$$
\text { S3: } \sum_{j=1}^{n}\left(w_{j} \mid a P_{j} b+a Q_{j} b+a I_{j} b\right)>\sum_{j=1}^{n}\left(w_{j} \mid a R_{j} b+b Q_{j} a+b P_{j} a\right)
$$

The context $S_{3}$ is characterized by the next fact: the sum of the weights of the criteria $j$ such what $a$ is strongly preferable $b$ and is weakly preferable $b$ and is indifferent $b$ is bigger than the sum of the weights of the criteria $j$ such what $a$ is weakly preferable $b$ more the sum of the weights of the criteria $j$ such what more the sum of the weights of the criteria $j$ such what her is not comparable with $b$ any more the sum of the weights of the criteria $j$ such what $b$ is weakly preferable her to any more the sum of the weights of the criteria $j$ such what $b$ is strongly 
DOI: 10.14807/ijmp.v12i8.1487

preferable to $a$. $R$ stands for non-comparability. $\mathrm{w}_{\mathrm{j}}, w$ are weight and $j$ are criteria $(\mathrm{j}=1,2, \ldots$, n).

It should be noted that the last two situations $\left(\mathrm{S}_{2}\right.$ and $\left.\mathrm{S}_{3}\right)$ are less rigorous than the first $\left(\mathrm{S}_{1}\right)$. This would lead to a smaller difference allowing one alternative to be ranked higher than another (Roy \& Bouyssou, 1993).

Situation $\mathrm{S}_{1}$ only consider the alternatives $a$ for which $a P b$, with $b$ being any other alternative. In this way, comparing $a$ with $b$, we can identify the criteria in which $a P b$. This would consider the thresholds of preference, indifference and discordance. A checking would verify if the condition imposed is satisfied. If satisfied, we know that $a$ dominates $b$. Afterwards, the criteria weights in which this condition was met are added. For another alternative $c$, the same procedure described previously is repeated. The final scoring of alternative $a$ will be the sum of the values obtained.

For the situation $\mathrm{S}_{2}$ the alternatives for which $a P b$ and $a Q b$ are considered. In situation $\mathrm{S}_{3}$, the alternatives for which $a P b, a Q b$ and $a I b$ are considered.

THOR 2 has an important difference with respect to the original THOR concerning the assignment of weights in the cases of indifference as well as weak preference in situations $\mathrm{S}_{1}$, $\mathrm{S}_{2}$ e $\mathrm{S}_{3}$. When indifference prevails, half of the respective criterion weight applies. Similarly, when weak preference occurs, a proportion between half of the criteria weight and the total weight value is assigned. (Tenório, 2020).

Additionally, THOR 2 takes into consideration that the value of the criterion weight is multiplied by a fuzzy-rough factor, thus contributing to downgrading the comparison in direct proportion to the importance and security of data. In other words, differently from the original THOR formulation, in THOR 2 situations where either strict preference, weak preference or indifference prevails, the criterion weight is multiplied by the fuzzy-rough index, thus taking into account the full uncertainty of the model, while in THOR that weight value is downgraded in the situation of weak preference only (Tenório, 2020). The calculations can be performed using a multicriteria platform named THOR Web, available through the website www.thorweb.com and developed at the Brazilian Military Engineering Institute (IME) located in Rio de Janeiro, Brazil.

Before we proceed showing how the two methods were separately applied to the same data one must clarify that both TODIM and THOR 2 are non-compensatory methods in the sense that tradeoffs do not occur (Bouyssou, 1986). Weights should in principle reflect to some 
DOI: 10.14807/ijmp.v12i8.1487

extent the degrees of relative importance or strength as estimated by decision agents along a numerical scale, such as from 0 to 10 . This scale can be either a linear, cardinal scale or a ratio scale. A comparatively high criterion weight increases the chance that an alternative well classified according to that criterion is positioned in a high global rank.

However, in some cases a relatively high weight for any given criterion does not necessarily mean that this is one of the most important criteria. For instance, given two conflicting criteria for completing a project, cost and time for completion, a decision maker initially considers cost as the most important among the two criteria. He therefore assigns a weight to cost that is much higher than the weight of time for completion. This is so because he expects to save some money to be assigned to other projects.

However, although some alternatives are close to reaching below $80 \%$ of the available budget, all alternatives are well above $90 \%$ of the time limit for completion. This is a typical situation in which an intracriteria analysis points out to the following fact: the criterion that had originally the smallest weight ends up being the most important between the two criteria.

\section{MODELING AND COMPUTATIONS}

\section{1. $\quad$ Problem Setting}

Problem structuring has been a quite important step when solving Management Science problems, and particularly multicriteria problems (Rosenhead \& Mingers, 2001; Belton \& Stewart, 2002). In this case study, however, the problem was set in a straightforward way by posing two questions: (1) given a well-established set of evaluation criteria, a set of technological alternatives (i.e., ballast water management methods) to reduce pollution caused by ballast water, and a set of restrictions that would apply in a variety of practical situations, which management methods would be considered the best by applying TODIM as well as by applying THOR 2? (2) what can we learn from comparing the two results?

The relevance of an effective assessment for water ballast management has been established in the specialized literature (Globallast, 2010, 2011). The detailed criteria, referring to the relevant factors identified, for quantitative measuring in association with a nominal scale or description, are presented below. Each criterion presented shall be analyzed and represented using quantitative measuring (Figure 1). This can be done by assigning either a value in a nominal scale, a yes or no answer, or by making use of an interval or ratio scale.

For this study, the following criteria were adopted: 
DOI: 10.14807/ijmp.v12i8.1487

(a) Restriction (or veto criterion) - the system to be incorporated or selected shall not present any restrictions unacceptable.

(b) All criteria have the same weight - although the participating experts had difficulty in achieving a consensus on the weights of criteria they felt it would be highly valuable to demonstrate that a well-structured and transparent multicriteria analysis could lead to a choice of technology.

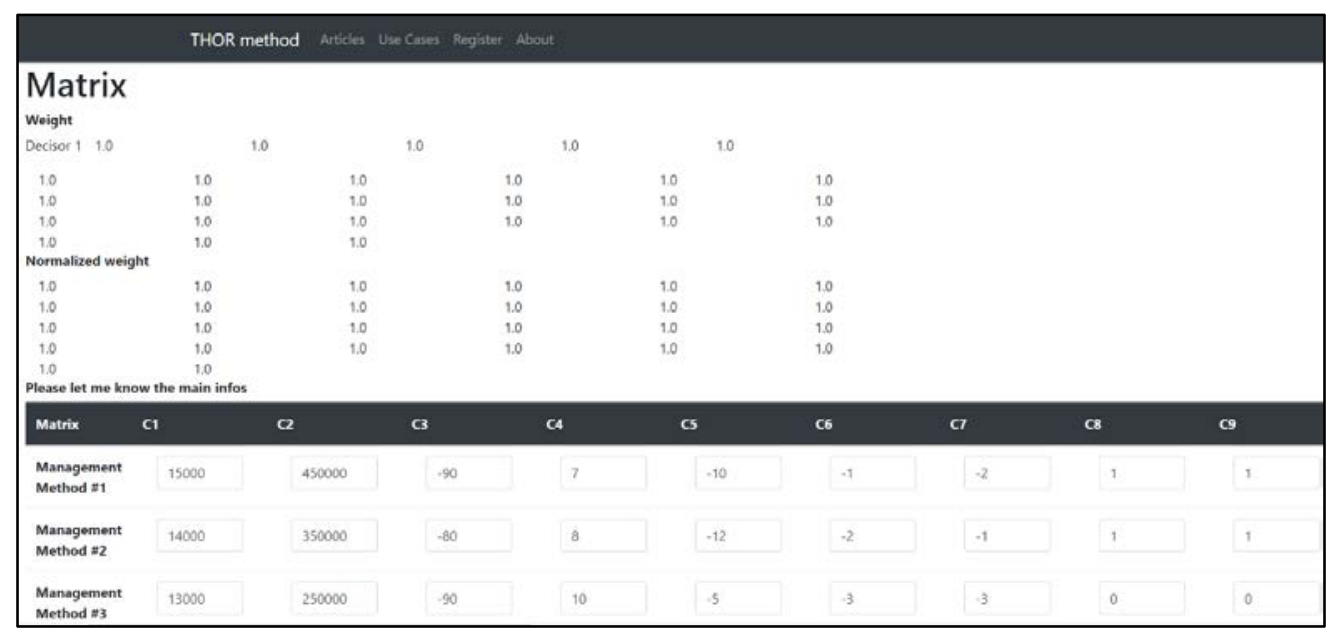

Figure 1: THOR Web Decision Matrix

\subsection{Criteria}

One week of extensive discussions led the experts to agree on the following list of evaluation criteria. An analysis then allowed to consider those criteria as being exhaustive, nonredundant and operational.

a) Practicality

a.1) Quantitative criteria:

$\mathrm{C}_{1}$ - what ballast flow rate range is the system applicable? $\left(\mathrm{m}^{3} /\right.$ hour) (specify the minimum and maximum flow rate)

$\mathrm{C}_{2}$ - what is the ship tonnage that the system can be applied to? (specify the minimum and maximum tonnage)

$\mathrm{C}_{3}$ - what is the additional workload on board? (man/hours)

$\mathrm{C}_{4}$ - what is the highest sea state (in the Beaufort wind scale) on which the system can operate?

$\mathrm{C}_{5}$ - what is the increase in tank's sediment caused by the system? (specify percentage) 
a.2) Questions that need to be answered by a nominal scale, subject to association to a numerical scale of intervals or by a yes/no answer:

$\mathrm{C}_{6}$ - does the system present any risks to the ship's crew safety or to the crew? (-3, high risk; -2, medium risk; -1, low risk; 0, no risk)

$\mathrm{C}_{7}$ - does the system affect the tanks' corrosion rate? (-2, increases the rate; -1 , does not increase the rate; 0 , reduces the rate)

C 8 - does the system dispense with the need to keep chemical products on board? (Yes or No)

$\mathrm{C}_{9}$ - can the system be used in short voyages (up to $12 \mathrm{~h}$ )? (Yes or No)

$\mathrm{C}_{10}$ - can the system be operated without complete re-circulation of the ballast water? (Yes or No)

$\mathrm{C}_{11}$ - is the system unaffected by incrustation that could lead to a drop in pressure and/or to a reduction in the flow rate? (Yes or No)

$\mathrm{C}_{12}$ - is the system being applicable to existing ships? (Yes or No)

$\mathrm{C}_{13}$ - are the ship's other functions independent from the system's operation? (Yes or No)

a.3) Questions that require detailed answers:

$\mathrm{C}_{14}$ - does the system present any occupational hazard to the operator? Describe and quantify. (-3, high; -2, medium; -1 , low; 0 , no hazard)

b) Biological effectiveness (including pathogens)

b.1) Quantitative Criteria:

C15 - how effective is the system in relation to the removal, elimination and inactivation/neutralization of aquatic organisms, apart from pathogens (according to the various taxonomic groups)? (quantify in terms of percentage, size and/or concentration of organisms)

C16 - same as 15 for pathogens.

b.2) Questions for which the answers should be either Yes or No

C17 - does the system eliminate cysts?

C18 - does the system allow the elimination of organisms when the water enters the $\operatorname{tank}$ ? 
DOI: 10.14807/ijmp.v12i8.1487

C19 - is the system adequate for the elimination of all species or life stages that may present a hazard to the environment?

c) Cost-benefit:

$\mathrm{C}_{20}$ - what is the purchase cost? (US\$)

$\mathrm{C}_{21}$ - what is the cost of installation? (US\$)

$\mathrm{C}_{22}$ - what is the operational cost? (US\$/ton)

$\mathrm{C}_{23}$ - what is the cost variation per ship size? (US\$/ton)

$\mathrm{C}_{24}$ - what is the increase of fuel or oil consumption that is introduced by the use of this system on board? (percentage)

d) Time frame within which the standards could be practically implemented

$\mathrm{C}_{25}$ - within which time frame could the standards be practically implemented? (no. of months)

e) Environmental impact of the process' sub-products

$\mathrm{C}_{26}$ - is the system free from generating sub-products that can have an impact on the environment?

Undesirable outcomes are taken with negative values as well as those that have a negative impact with higher absolute values. This leads to the following: $i$ ) In the criteria 3, 5, 20-24 and 25, negative values are assign for the lowest desirable feature; ii) In the criteria 8 to 13, 17, 18, 19 and 26, where the answers should be either "Yes" or "No", a value of 1 was assigned to a "Yes" answer (desirable) and a value of 0 to a "No" answer (undesirable); and iii) In the criteria 6, 7 and 14, verbal (or nominal) scales associated to a numerical scale have been created for test purposes.

\subsection{Alternatives}

Ballast water management technologies can be of two types: no ballast or zero discharge methods, and continuous flow methods. Research of economic valuations are intended to improve decision-making processes ranging from community or industry engagement and ecosystem management to the development of national strategies and action plans to manage the risk associated with invasive alien species (Globallast, 2010, 2011, 2020a, 2020b).

After a carefully, first screening, three competitive, alternative ballast water management technologies were identified. The nineteen professionals participated full-time in 


\section{INDEPENDENT JOURNAL OF MANAGEMENT \& PRODUCTION (IJM\&P)}

http://www.ijmp.jor.br

v. 12, n. 8, November-December 2021

ISSN: 2236-269X

DOI: 10.14807/ijmp.v12i8.1487

that first screening, that took two weeks. The studies in Brazil took more than five months. The alternatives to be analyzed are named in this article Management Method \#1, Management Method \#2, and Management Method \#3. Management methods \#1 and \#2 are flow methods, while Management Method \#3 is a zero discharge method. They are described in Table 1 . These three alternatives were considered as feasible by experts.

\subsection{Evaluation Matrix}

The evaluation matrix is presented in Table 2. This Table presents an example utilization of this method using the three Management Methods \#1, \#2 and \#3. It is difficult, just by looking at Table 1, to identify the best management method. This problem becomes even more complicated if we consider that there are several ballast water treatment methods currently being discussed at IMO and not just the three ones used as example.

Table 2: Evaluation matrix.

\begin{tabular}{|c|c|c|c|}
\hline \multirow[t]{2}{*}{ Criteria } & \multicolumn{3}{|c|}{ Alternatives } \\
\hline & Management Method \#1 & Management Method \#2 & Management Method \#3 \\
\hline $\mathrm{C}_{1}$ & $\begin{array}{l}\text { Maximum: } 15,000 \mathrm{~m}^{3} / \mathrm{h} \\
\text { Minimum: } 100 \mathrm{~m}^{3} / \mathrm{h}\end{array}$ & $\begin{array}{l}\text { Maximum: } 14,000 \mathrm{~m}^{3} / \mathrm{h} \\
\text { Minimum: } 200 \mathrm{~m}^{3} / \mathrm{h}\end{array}$ & $\begin{array}{l}\text { Maximum: } 13,000 \mathrm{~m}^{3} / \mathrm{h} \\
\text { Minimum: } 300 \mathrm{~m}^{3} / \mathrm{h}\end{array}$ \\
\hline $\mathrm{C}_{2}$ & $\begin{array}{l}\text { Maximum: 450,000 DWT } \\
\text { Minimum: 450 DWT }\end{array}$ & $\begin{array}{l}\text { Maximum: 350,000 DWT } \\
\text { Minimum: 350 DWT }\end{array}$ & $\begin{array}{l}\text { Maximum: 250,000 DWT } \\
\text { Minimum: 450 DWT }\end{array}$ \\
\hline $\mathrm{C}_{3}$ & $90 \mathrm{man} / \mathrm{hour}$ & $80 \mathrm{man} /$ hour & $90 \mathrm{man} /$ hour \\
\hline $\mathrm{C}_{4}$ & 7 & 8 & 10 \\
\hline $\mathrm{C}_{5}$ & $10 \%$ & $12 \%$ & $5 \%$ \\
\hline $\mathrm{C}_{6}$ & -1 & -2 & -3 \\
\hline $\mathrm{C}_{7}$ & -2 & -1 & -3 \\
\hline $\mathrm{C}_{8}$ & 1 & 1 & 0 \\
\hline $\mathrm{C}_{9}$ & 1 & 1 & 0 \\
\hline $\mathrm{C}_{10}$ & 1 & 1 & 0 \\
\hline $\mathrm{C}_{11}$ & 0 & 1 & 1 \\
\hline $\mathrm{C}_{12}$ & 0 & 1 & 1 \\
\hline $\mathrm{C}_{13}$ & 0 & 0 & 1 \\
\hline $\mathrm{C}_{14}$ & 0 & -1 & -2 \\
\hline $\mathrm{C}_{15}$ & $93 \%$ & $92 \%$ & $90 \%$ \\
\hline $\mathrm{C}_{16}$ & $90 \%$ & $88 \%$ & $91 \%$ \\
\hline $\mathrm{C}_{17}$ & 1 & 0 & 1 \\
\hline $\mathrm{C}_{18}$ & 1 & 0 & 0 \\
\hline $\mathrm{C}_{19}$ & 0 & 1 & 1 \\
\hline $\mathrm{C}_{20}$ & US\$ $200,000.00$ & US\$ $210,000.00$ & US\$ 220,000.00 \\
\hline $\mathrm{C}_{21}$ & US\$ $10,000.00$ & US\$ $21,000.00$ & US\$ $1,000.00$ \\
\hline $\mathrm{C}_{22}$ & 0.02 US\$/ton & $0.03 \mathrm{US} \$ /$ ton & 0.04 US\$/ton \\
\hline $\mathrm{C}_{23}$ & US\$ 9 & US\$ 8 & US\$ 6 \\
\hline $\mathrm{C}_{24}$ & $3 \%$ & $8 \%$ & $1 \%$ \\
\hline $\mathrm{C}_{25}$ & 6 months & 8 months & 9 months \\
\hline $\mathrm{C}_{26}$ & 0 & 1 & 0 \\
\hline
\end{tabular}

All values in the above matrix were normalized and transformed into maximization criteria for the use of the TODIM method. The THOR 2 method used data as shown in Table 
DOI: 10.14807/ijmp.v12i8.1487

2. From now in this article on Management Methods \#1, \#2, and \#3 will be designated as A1, A2 and A3.

\section{5. $\quad$ Results}

The application of TODIM took into consideration three possible situations: (i) attenuation factor $\theta$ equal to 1.0 (less risk proneness); (ii) $\theta$ equal to 10.0 (greater risk proneness); and (iii) $\theta$ equal to 5.0 (an intermediate value between the two previous extreme situations). Results from the computations are presented in Table 3.

Table 3: Performance of the three alternatives according to the TODIM method.

\begin{tabular}{|c|c|c|c|}
\hline Alternatives & $\theta=1.0$ & $\theta=5.0$ & $\theta=10.0$ \\
\hline $\mathrm{A}_{1}$ & 1.000 & 1.000 & 1.000 \\
\hline $\mathrm{A}_{2}$ & 0.808 & 0.000 & 0.000 \\
\hline $\mathrm{A}_{3}$ & 0.000 & 0.210 & 0.425 \\
\hline
\end{tabular}

The application of THOR 2 considered the situations $\mathrm{S}_{1}$. Table 4 shows the outputs from using THOR 2.

Table 4: THOR 2 results

\begin{tabular}{|c|c|c|c|c|c|}
\hline $\mathrm{S}_{1}$ & & $\mathrm{~S}_{2}$ & & $\mathrm{~S}_{3}$ & \\
\hline A1 & 1.114 & A1 & 1.114 & A1 & 1.259 \\
\hline A2 & 0.583 & A2 & 0.583 & A2 & 0.667 \\
\hline A3 & 0.000 & A3 & 0.000 & A3 & 0.000 \\
\hline
\end{tabular}

The three alternatives were evaluated according to criteria 1, 2, 3, 20, 21, 22, 23 and 25 on a ratio scale. Alternatives were evaluated according to criteria 5, 15 and 16 by an interval scale. Alternatives were evaluated with respect to all other criteria by using a nominal scale associated to an interval scale.

\section{DISCUSSION AND CONCLUSIONS}

It is worth noting that although the two methods rely on different foundations they produced in essence the same results. Two other applications of both TODIM and THOR have indeed confirmed the convergence of results in spite of the conceptual and technical differences between the two methods. The present result from applying TODIM and THOR 2 is therefore consistent with the results obtained by Gomes et al. (2009) and Gomes et al. (2010).

The TODIM method is founded on the paradigm of Prospect Theory and data are aggregated by means of building an additive value function. On the other hand, THOR 2 relies on the notion of outranking and does not directly take into account the attitude of a decision maker facing risk. The fact that both TODIM and THOR 2 produce similar results suggests that formulating a decision problem in a comprehensive way and applying a method correctly may be at least as important as the technical characteristics of the method per se. 
DOI: 10.14807/ijmp.v12i8.1487

A1 was chosen as the best alternative when both TODIM and THOR 2 are used in the situation when $\theta$ is made equal to 1.0. When $\theta$ was equal to 5.0 and 10.0 , however, there was a discordance between TODIM and THOR 2 concerning the last two alternatives: A1 is preferred to A3 and A3 is preferred to A2 from TODIM and A1 is preferred to A2 and A2 is preferred to A3 from THOR 2.

Nevertheless, since this was a problem in the choice of a technology, for practical purposes it was concluded that the two methods produced similar results. The final results show that A1 should be the best choice. Given that participants in the evaluation study understood the use of the methods, this convergence of results led to widely accepted recommendation to decision makers.

\section{ACKNOWLEDGEMENTS}

The study presented in this paper was partially supported by CNPq through Project No. 306562/2017-0.

\section{REFERENCES}

Belton, V., \& Stewart, T. J. (2002). Multiple Criteria Decision Analysis. Kluwer, Boston. Bouyssou, D. (1986). Some remarks on the notion of compensation in MCDM. European Journal of Operational Research, 26 (1), p 150-160.

Brans, J. P., \& Mareschal, B. (1990). The PROMÉTHÉE methods for MCDM, the PROMCALC GAIA and BANKADVISER software. In Readings in Multiple Criteria Decision Aid (edited by C.A. Bana e Costa), chapter 2, Springer, Berlin.

Cardoso, R. S., Xavier, L. H., Gomes, C. F. S., \& Adissi, P. J. (2009). Uso de SAD no apoio à decisão na destinação de resíduos plásticos e gestão de materiais. Pesquisa Operacional, 29( 1), 67-95.

Costa, I. P. A., Maêda, S. M. N., Teixeira, L. F. H. S. B., Gomes, C. F. S., \& Santos, M. (2020). Escolha de navio de assistência hospitalar no combate à pandemia da covid-19.

Revista de Saúde Pública, 54, 79. EPUB, August 10, 2020. https://doi.org/10.11606/s15188787.2020054002792

Clemen, R. T., \& Reilly, T. (2001). Making Hard Decisions with Decision Tools ${ }^{\circledR}$, Duxbury-Thomson Learning, Pacific Grove.

Costa, I. P. A., Gomes, C. F. S., Teixeira, L. F. H. S. B., Santos, M., \& Maeda, S. (2020). Choosing a hospital assistance ship to fight the COVID-19 pandemic. Revista de Saúde Pública, 54, 1-8.

Ehrgott, M., Figueira, J. R., \& Greco, S. (eds.) (2010). Trends in Multiple Criteria Decision Analysis, Springer, New York.

Globallast (2010). Economic Assessments for Ballast Water Management: A Guideline. GloBallast Partnerships Project Coordination Unit and International Maritime Organization, London, GloBallast Monograph Series, N. 19. 
Globallast (2011). Establising Equivalency in the Performance Testind and Compliance Monitoring of Emerging Alternative Ballast Water Management Systems. GloBallast Partnerships Project Coordination Unit and International Maritime Organization, London, GloBallast Monograph Series, N. 20.

Gomes, C. F. S. (1999). THOR - Um Algoritmo Híbrido de Apoio Multicritério à Decisão para Processos Decisórios com Alternativas Discretas. Tese de doutorado em Engenharia de Produção, Universidade Federal do Rio de Janeiro, Brasil.

Gomes, C. F. S. (2005). Using MCDA methods THOR in an application for outranking the ballast water management options. Pesquisa Operacional, 25, Jan/April, p 11-28.

Gomes, C. F. S. (2006). Modelagem analítica aplicada à negociação e decisão em grupo. Pesquisa Operacional, 26(3), 537-566.

Gomes, C. F. S., \& Costa, H. G. (2015). Aplicação de métodos multicritério ao problema de escolha de modelos de pagamento eletrônico por cartão de crédito. Production, 25(1), 54-68.

Gomes, C. F. S., Gomes, L. F. A. M., \& Maranhão, F. J. C. (2010). Decision analysis for the exploration of gas reserves: merging TODIM and THOR. Pesquisa Operacional, 30(3), 601617.

Gomes, C. F. S., \& Maia, A. C. C. (2013). Ordenação de alternativas de biomassa utilizando o apoio multicritério à decisão. Production, 23(3), 488-499.

Gomes, L. F. A. M. (1989). Multicriteria ranking of urban transportation system alternatives. Journal of Advanced Transportation, 23(1), 43-52.

Gomes, L. F. A. M. (1989). Comparing two methods for multicriteria ranking of urban transportation system alternatives. Journal of Advanced Transportation, 23(2\&3), 217219.

Gomes, L. F. A. M. (1990). Modelling interdependencies among urban transportation system alternatives. Journal of Advanced Transportation,24( 1, 77-85.

Gomes, L. F. A. M. (1990). Eliminating rank reversal in multicriteria analysis of urban transportation system alternatives. Journal of Advanced Transportation,24(2), 181-184.

Gomes, L. F. A. M., Gomes, C. F. S., Rangel, L. A. D. (2009). A comparative decision analysis with THOR and TODIM: rental evaluation in Volta Redonda. Revista Tecnologia, 30(1), 7-11.

Gomes, L. F. A. M., \& Lima, M. M. P. P. (1991). TODIM: basics and application to multicriteria ranking of projects with environmental impacts. Foundations of Computing and Decision Sciences,16(4), 113-127.

Gomes, L. F. A. M., \& Lima, M. M. P. P. (1992). From modeling individual preferences to multicriteria ranking of discrete alternatives: a look at Prospect Theory and the additive difference model. Foundations of Computing and Decision Sciences,17(3), p 171-184.

Gomes, L. F. A. M., Machado, M. A. S., González, X. I., \& Rangel, L. A. D. (2013). Behavioral multi-criteria decision analysis: the TODIM method with criteria interactions. Annals of Operations Research, 211(1), p 531-548.

Gomes, C. F. S., Nunes, K. R. A., Xavier, L. H., Cardoso, R., \& Valle, R. (2008).

Multicriteria decision making applied to waste recycling in Brazil. Omega, 36, p 395-404. 
Gomes, L. F. A. M., \& Rangel, L. A. D. (2009). An application of the TODIM method to the multicriteria rental evaluation of residential properties. European Journal of Operational Research, 193, 204-211.

Gomes, L. F. A. M., Rangel, L. A. D., \& Maranhão, F. J. C. (2009). Multicriteria analysis of natural gas destination in Brazil: an application of the TODIM method. Mathematical and Computer Modelling, 50, 92-100.

IMO (2020a). Ballast Water Management.

http://www.imo.org/en/OurWork/Environment/BallastWaterManagement/Pages/Default.aspx . Access: 10/09/2020.

IMO (2020b). Welcome to GloBallast.

http://globallast.imo.org/index.asp?page=problem.htm\&menu=true. Access: 10/09/2020.

Kahneman, D., \& Tversky, A. (1979). Prospect theory: An analysis of decision under risk.

Econometrica, 47, 263-292.

Keeney, R. L., \& Raiffa, H. (1993). Decisions with Multiple Objectives: Preferences and Value Tradeoffs, Cambridge University Press, Cambridge.

Rosenhead, J., Mingers, J. (eds) (2001). Rational Analysis for a Problematic World Revisited, Wiley, Chichester.

Roy, B. (1996). Multicriteria Methodology for Decision Aiding, Kluwer, Dordrecht.

Roy, B., \& Bouyssou, D. (1993). Aide Multicritère à la Décision: Méthodes et Cas, Economica, Paris.

Sudha, A. S., Gomes, L. F. A. M., \& Vijayalakshmi, K. R. (2020). Assessment of MCDM problems by TODIM using aggregated weights. Neutrosophic Sets and Systems, 35, 78-98.

Tenenbaum, D. R., Villac, M. C., Viana, S. C., Matos, M., Hatherly, M., Lima, I. V., \& Menezes, M. (2004). Phytoplankton Atlas of Sepetiba Bay, Rio de Janeiro, Brazil.

GloBallast Partnerships Project Coordination Unit and International Maritime

Organization, London, GloBallast Monograph Series, N. 16.

Tenório, F. M. (2020). Modelagem multicritério: uma evolução do método THOR.

Dissertação (Mestrado em Sistemas e Computação) - Instituto Militar de Engenharia, Rio de Janeiro, Available: http://www.comp.ime.eb.br/pos/modules/files/dissertacoes/2020/2020-

Fabricio.pdf. Access: 31/12/2020.

Tenorio, F. M., Santos, M., Gomes, C. F. S., \& Araujo, J. C. (2020a). Estratégia para compra de oportunidade de uma fragata para a Marinha do Brasil a partir do método multicritério THOR. Revista Valore, 5, 43-57.

Tenorio, F. M., Santos, M., Gomes, C. F. S., Araujo, J. C. (2020b). Navy Warship Selection and Multicriteria Analysis: The THOR Method Supporting Decision Making. In: Thomé, A. M. T., Barbastefano, R. G., Scavarda, L. F., dos Reis, J. C. G., \& Amorim, M. P. C. (eds.) Industrial Engineering and Operations Management. IJCIEOM 2020. Springer Proceedings in Mathematics \& Statistics, 337. Springer, Cham. https://doi.org/10.1007/9783-030-56920-4_3

Tversky, A. (1969). Intransitivity of Preferences. Psychological Review, 76(1), 31-48.

Zindani, D., Maity, S. R., \& Bhowmik, S. (2020). Complex interval-valued intuitionistic fuzzy TODIM approach and its application to group decision making. Journal of Ambient Intelligence and Humanized Computing. Published online: 16 July 2020.

https://doi.org/10.1007/s12652-020-02308-0. 